\title{
Akuntabilitas Perencanaan Kebutuhan dan Penganggaran Aset Tetap Pemerintah Kota Salatiga
}

\author{
Mega Andhita ${ }^{1 *}$, Usil Sis Sucahyo ${ }^{2}$ \\ 1,2Universitas Kristen Satya Wacana
}

\section{A R T I C L E I N F O}

Article history:

Received 15 February 2020

Received in revised form 30 March 2020

Accepted 20 April 2020

Available online 28 May 2020

Kata Kunci:

Akuntabilitas,

Penganggaran Modal, Aset tetap

Keywords:

Accountability, Capital Budgeting, Fixed assets

\begin{abstract}
A B S T R A K
Penelitian ini didorong oleh masih adanya beberapa ketidakselarasan dokumen dalam proses perencanaan ktetap di Kota Salatiga. Oleh karena itu penelitian ini ditujukan untuk mendeskripsikan akuntabilitas proses perencanaan kebutuhan dan penganggaran asset tetap di Pemerintah Kota Salatiga. Pertanyaan yang mau di jawab yaitu bagaimana mekanisme perencanaan kebutuhan dan penganggaran asset tetap Kota Salatiga, dan apakah mekanisme akuntabilitas Pemerintah Kota Salatiga yang akuntabel. Penelitian ini adalah penelitian kualitatif dengan metode analisis data adalah deskriptif kualitatif. Hasil penelitian menunjukkan bahwa mekanisme perencanaan kebutuhan dan penganggaran aset tetap Pemerintahan Kota Salatiga sudah melalui Renstra, Musrenbang, RKA SKPD, KUA PPAS, Nota Kesepakatan dan output terakhir berupa DPA SKPD. Sedangkan untuk mekanisme akuntabilitas perencanaan kebutuhan dan penganggaran aset tetap Pemerintah Kota Salatiga dapat dilihat dari pemenuhan dokumen berdasarkan Permendagri 19 tahun 2016 baik untuk perencanaan kebutuhan maupun penganggaran. Selain itu akuntabilitas berdasarkan perundang-undangan Pemerintah Kota Salatiga sudah menyesuaikan kebijakan dan perubahan amandemen.
\end{abstract}

A B S T R A C T

This research is driven by incomplete documents in the process of fixed asset planning in Salatiga. Therefore this study aims to describe the accountability of the planning process and budgeting of fixed assets in the Salatiga Municipal Government. The question that must be answered is how to plan the planning and budgeting of Salatiga City's fixed assets, and whether the accountability of the Salatiga City Government is accountable. This research is a qualitative research with descriptive qualitative data analysis method. The results showed that the mechanism for planning needs and budgeting of fixed assets of the Salatiga City Government had gone through the Strategic Plan, Musrenbang, RKA SKPD, KUA PPAS, Memorandum of Understanding and the final results in the form of DPA SKPD. Whereas the accountability mechanism for planning needs and budgeting of fixed assets of the Salatiga City Government can be seen from the fulfillment of documents based on Permendagri 19 of 2016 both for needs planning and budgeting. In addition, accountability based on the laws of the Salatiga City Government has adjusted the policies and amendment changes.

\footnotetext{
* Corresponding author.

E-mail addresses: megadhita12@gmail.com (Mega Andhita)
} 


\section{Pendahuluan}

Perubahan paradigma pemerintah dalam pemberian hak otonomi kepada setiap daerah ditandai dengan Peraturan Pemerintah Nomor 23 Tahun 2014 yang mengemukakan setiap daerah diberikan keleluasaan untuk menetapkan peraturan dan mempertanggungjawabkan atas aturan yang ditetapkan. Penetapan peraturan ini bertujuan untuk mensejahterakan masyarakat dapat dicapai melalui akuntabilitas. Kamaluddin (2019) menjelaskan akuntabilitas didefinisikan sebagai pertanggungjawaban pejabat publik untuk dapat menjelaskan kesesuaian mekanisme pertanggungjawaban dan peraturan perundang-undangan yang ada kepada masyarakat maupun Lembaga- Lembaga yang berkepentingan. Berdasarkan pengertian tersebut maka Pemerintah Pusat maupun Daerah harus memahami cakupan akuntabilitasnya masing-masing, sebab akuntabilitas mempengaruhi keberhasilan atau kegagalan tujuan instansi bersangkutan (Hartanto, 2018). Akuntabilitas pun perlu dilakukan dalam mengelola aset tetap, sebab merupakan aset yang nilainya besar dari keseluruhan aset yang dimiliki.

Aset dalam perusahaan terdiri dari dua jenis, yaitu: aset lancar dan aset tetap. Aset lancar merupakan aset perusahaan yang memiliki masa manfaat kurang dari satu tahun. Sedangkan aset tetap merupakan aset perusahaan yang memiliki masa manfaat lebih dari satu tahun. Aset tetap digolongkan menjadi dua golongan, yaitu: aset tetap berwujud dan aset tetap tidak berwujud. Aset tetap berwujud contohnya: mesin, peralatan, kendaraan, bangunan dan tanah. Aset tetap tidak berwujud, contohnya: software, merek dagang, lisensi dan formula, resep, desain dan lainlain. Aset tetap dapat diperoleh dengan berbagai cara, yaitu: pembelian, pembangunan, serta sumbangan. Perusahaan perlu melakukan perawatan secara berkala terhadap aset tetap, agar mengurangi resiko penghentian pemakaian aset tetap karena kerusakan (Hartoko, 2017).

Kamaluddin (2019) menjelaskan akuntabilitas didefinisikan sebagai pertanggungjawaban pejabat publik untuk dapat menjelaskan kesesuaian mekanisme pertanggungjawaban dan peraturan perundangundangan yang ada kepada masyarakat maupun Lembag- Lembaga yang berkepentingan.Berdasarkan UU 32 Tahun 2004, yang dijabarkan pada Pasal 27 ayat (2) Kepala daerah mempunyai kewajiban juga untuk memberikan laporan penyelenggaraan pemerintah daerah kepada Pemerintah, dan memberikan laporan keterangan pertanggungjawaban kepada DPR, serta menginformasikan laporan penyelenggaraan pemerintah daerah kepada masyarakat; ayat (3) Laporan penyelenggaraan pemerintah kepada Pemerintah sebagaimana dimaksud pada ayat (2) disampaikan kepada Presiden melalui Menteri Dalam Negeri untuk Gubernur, dan Menteri Dalam Negeri melalui Gubernur untuk Bupati/Walikota satu kali dalam satu tahun; ayat (4) Laporan sebagaimana dimaksud dalam ayat (3) digunakan pemerintah sebagai dasar melakukan evaluasi penyelenggaraan pemerintah daerah dan sebagai bahan pembinaan lebih lanjut sesuai dengan peraturan perundang-undangan.

Berdasarkan Peraturan Menteri Dalam Negeri (Permendagri) No.17 pasal 4 tahun 2007, terdapat beberapa proses pengelolaan aset, yaitu: perencanaan kebutuhan dan penganggaran; pengadaan; penggunaan; penatausahaan; pemanfaatan; pengamanan dan pemeliharaan; penilaian; penghapusan; pembinaan, pengawasan dan pengendalian; proses pemindahtanganan; pembiayaan; dan tuntutan ganti rugi. Wonggow et al., (2014) mengemukakan bahwa tujuan dari keseluruhan proses yaitu untuk meningkatkan keefektifan, keefisienan, transparan dan akuntabel yang dapat dipertanggungjawabkan kepada masyarakat atau publik.

Hartanto (2018) menyatakan tahapan-tahapan tersebut saling berkaitan. Hal ini sependapat dengan Nihayati et al., (2019), sehingga riset sebelumnya membahas keseluruhan proses namun secara garis besar saja. Lain halnya dengan penelitian ini, peneliti hanya menggunakan prosedur perencanaan kebutuhan dan penganggaran sebagai dasar penelitian. Sebab peneliti menyetujui pendapat Pinatik, Ilat \& Kolinug (2015) yang menyatakan pelaksanaan siklus perencanaan dan penganggaran yang kurang baik menyebabkan proses pengelolaan aset lainnya menjadi tidak optimal. Pendapat ini diperkuat Labasido \& Darwanis (2019) yang menyatakan perencanaan kebutuhan dan penganggaran seharusnya sesuai dengan mekanisme peraturan, sebab perencanaan kebutuhan dan penganggaran merupakan dasar untuk tahapan lainnya.

Pemerintah Kota Salatiga pada dasarnya sudah menjalankan proses pengelolaan aset tetap dengan mengacu pada Peraturan Menteri Dalam Negeri (Permendagri) No.17 pasal 4 tahun 2007. Namun, Laporan Kinerja Instansi Pemerintah (LKjIP) menampilkan adanya masalah perencanaan pada tahun 2018, salah satunya adalah adanya ketidakselarasan antar dokumen perencanaan. Dalam LKjIP tidak dinyatakan secara jelas letak ketidak selarasan tersebut. Dokumen perencanaan ini diindikasi peneliti terjadi dalam mekanisme perencanaan kebutuhan dan penganggaran. Penyebabnya dikarenakan terdapat perbedaan dalam menuliskan kode akun barang Milik Daerah sesuai dengan Peraturan Menteri dalam Negeri dengan kode akun akuntansi. Hal ini disebabkan kurangnya koordinasi dan ketegasan dalam hal 
pelaporan dokumen tersebut. Sehingga terjadi perbedaan jumlah penganggaran yang dicatat dan yang sebenarnya.

Penelitian Tangkuman \& Mulalinda (2014) pada aset tetap Kabupaten Sitaro telah dilakukan namun hanya menekankan proses pengadaan, penggunaan, penyimpanan, pemanfaatan, penghapusan, pemeliharaan dan pengamanan. Hal ini kembali diteliti oleh Hartanto (2018) di Kabupaten Ciamis untuk keseluruhan prosedur aset tetap. Hasil penelitiannya menunjukkan Peraturan Pemerintah Nomor 27 Tahun 2014 menjadi penyebab utama tidak terlaksananya dua belas proses tersebut. Adapun penelitian dari Nihayati et al., (2019) yang menekankan ketidakmasimal prosedur pengadaan, pengamanan dan pengendalian, penghapusan dan pemindahtanganan, pembinaan, penatausahaan, pelaporan dan penilaian karena tidak sejalan dengan Permendagri Nomor 1 Tahun 2016.

Berdasarkan uraian pendahuluan di atas, maka peneliti merumuskan beberapa pertanyaan, yaitu: (1) Bagaimana mekanisme perencanaan kebutuhan dan penganggaran aset tetap Pemerintah Kota Salatiga? (2) Bagaimana mekanisme akuntabilitas perencanaan kebutuhan dan penganggaran yang akuntabel?. Sehingga penelitian ini bertujuan untuk mengetahui mekanisme akuntabilitas perencanaan kebutuhan dan penganggaran yang akuntabel pada Pemerintahan Kota Salatiga. Adapun manfaat penelitian ini yaitu dapat menambah wawasan terkait perencanaan kebutuhan dan penganggaran khususnya aset tetap. Selain itu manfaat bagi Pemerintah Kota Salatiga, diharapkan penelitian ini dapat memberikan kontribusi dan menjadi referensi bagi penelitian selanjutnya terkait dengan perencanaan kebutuhan dan penganggaran aset tetap.

\section{Metode}

Penelitian ini menggunakan analisis deskriptif kualitatif di Pemerintah Kota Salatiga. Data terkait mekanisme perencanaan kebutuhan dan penganggaran aset tetap yang akuntabel diperoleh dari wawancara dengan Satuan Kerja Perangkat Daerah (SKPD) Badan Perencanaan, Penelitian dan Pengembangan Daerah (Bappeda) dan SKPD Badan Keuangan Daerah (BKD). Narasumber SKPD Bappeda ialah Kepala Bidang Penelitian dan Pengembangan, sedangkan untuk SKPD BKD ialah, Kepala Bidang Anggaran dan Belanja, dan Kasubbag Aset. Pemilihan narasumber berdasarkan keterkaitannya tugas pokok dan fungsi terkait perencanaan kebutuhan dan penganggaran aset tetap Kota Salatiga.

Informasi yang diperlukan tidak hanya diperoleh dari wawancara, melainkan dengan mengumpulkan dokumen terkait yang dapat diperoleh dari situs resmi pemerintah Kota Salatiga atau dengan mendatangi langsung kantor SKPD Bappeda dan BKD. Dokumen yang diperlukan ialah: (a) Rencana Kebutuhan Barang Milik Daerah (RKBMD); (b) Rencana Kebutuhan Pemeliharaan Barang Milik Daerah (RKPBMD); (c) Daftar Kebutuhan Barang Milik Daerah (DKBMD); (d) Daftar Kebutuhan Pemeliharaan Barang Milik Daerah (DKPBMD); (e) Laporan perhitungan APBD; (f) Nota perhitungan APBD; (g) Laporan aliran Kas; dan (h) Neraca Daerah.

Teknik analisis data dilakukan dengan reduksi data yaitu membuat rangkuman inti dan mengklasifikasikan sesuai dengan masalah yang diteliti. Sub yang direduksi ialah mekanisme perencanaan kebutuhan dan penganggaran aset tetap kota Salatiga. Penyajian data dilakukan dengan membuat teks naratif sehingga dapat memudahkan dan bertujuan untuk melihat gambaran penelitian secara menyeluruh atau bagian-bagian tertentu dari hasil penelitian. Setelah itu akan di analisis dengan landasan pendapat berdasarkan dengan para ahli untuk dapat dilakukan upaya penarikan kesimpulan.

\section{Hasil dan pembahasan}

\section{A. Gambaran Aset}

Berdasarkan catatan atas laporan keuangan (CALK), nilai aset tetap Pemerintah Kota Salatiga per 31 Desember 2018 sebesar Rp3.289.063.056.248,83. Jika dibandingkan dengan jumlah aset tetap pada tahun 2017 sebesar Rp.3.215.249.253.145,86, maka terjadi peningkatan sebesar Rp73.813.803.102,96 atau meningkat sebesar $2,30 \%$. 
Tabel 1. Rincian Penambahan dan Pengurangan Aset

\begin{tabular}{|c|c|c|c|c|c|}
\hline No & Aset Tetap & $\begin{array}{ll}31 & \text { Desember } \\
2017 & \end{array}$ & Penambahan & Pengurangan & 31 Desember 2018 \\
\hline 1 & Tanah & $\begin{array}{l}1.479 .384 .253 .4 \\
34,01\end{array}$ & $\begin{array}{l}14.082 .984 .024,0 \\
0\end{array}$ & $\begin{array}{l}57.815 .407 .835,3 \\
5\end{array}$ & $\begin{array}{l}1.435 .651 .829 .622,6 \\
6\end{array}$ \\
\hline 2 & $\begin{array}{l}\text { Peralatan } \\
\text { dan Mesin }\end{array}$ & $\begin{array}{l}402.922 .063 .51 \\
5,34\end{array}$ & $\begin{array}{l}95.260 .458 .494,7 \\
9\end{array}$ & $\begin{array}{l}28.782 .222 .522,2 \\
1\end{array}$ & 469.400.299.487,92 \\
\hline 3 & $\begin{array}{l}\text { Gedung } \\
\text { dan } \\
\text { Bangunan }\end{array}$ & $\begin{array}{l}420.278 .544 .01 \\
6,02\end{array}$ & $\begin{array}{l}135.540 .578 .468, \\
52\end{array}$ & $\begin{array}{l}42.425 .373 .408,6 \\
1\end{array}$ & $513.393 .749 .075,93$ \\
\hline 4 & $\begin{array}{l}\text { Jalan, } \\
\text { Irigasi dan } \\
\text { Jaringan }\end{array}$ & $\begin{array}{l}826.370 .727 .31 \\
1,11\end{array}$ & $\begin{array}{l}136.627 .228 .003, \\
12\end{array}$ & $\begin{array}{l}174.538 .892 .481, \\
86\end{array}$ & $788.459 .062 .832,37$ \\
\hline 5 & $\begin{array}{l}\text { Aset Tetap } \\
\text { Lainnya }\end{array}$ & $\begin{array}{l}35.148 .648 .717, \\
47\end{array}$ & $\begin{array}{l}17.663 .364 .072,5 \\
9\end{array}$ & $\begin{array}{l}22.053 .542 .811,1 \\
7\end{array}$ & $30.758 .469 .978,89$ \\
\hline 6 & $\begin{array}{l}\text { Konstruksi } \\
\text { Dalam } \\
\text { Pengerjaa } \\
\text { n }\end{array}$ & $\begin{array}{l}51.145 .016 .151, \\
92\end{array}$ & $\begin{array}{l}26.552 .149 .000,0 \\
0\end{array}$ & $\begin{array}{l}26.297 .519 .900,8 \\
6\end{array}$ & $51.399 .645 .251,06$ \\
\hline & Jumlah & $\begin{array}{l}3.215 .249 .253 .1 \\
45,86\end{array}$ & $\begin{array}{l}425.726 .762 .063, \\
02\end{array}$ & $\begin{array}{l}351.912 .958 .960, \\
06\end{array}$ & $\begin{array}{l}3.289 .063 .056 .248,8 \\
3\end{array}$ \\
\hline
\end{tabular}

Nilai aset tetap Pemerintah Kota Salatiga per 31 Desember 2018 sebesar Rp.3.289.063.056.248,83, setelah dikurangi akumulasi penyusutan sebesar Rp.771.286.535.093,16 adalah sebesar Rp.2.517.776.521.155,67. Berikut penjelasan terkait kelompok dan jumlah aset tetap pada tahun 2018:

a) Tanah Pemerintah Kota Salatiga pada tahun 2018 sebesar Rp.1.435.651.829.622,66. Jika dibandingkan dengan jumlah aset Tanah per 31 Desember 2017 sebesar Rp1.479.384.253.434,01 maka terdapat penurunan tanah sebesar Rp43.732.423.811,35 atau menurun sebesar 0,03 \%. Tanah yang dikelompokkan sebagai aset tetap adalah tanah yang diperoleh dengan maksud dipakai dalam kegiatan operasional Pemerintah Kota Salatiga, termasuk yang dipakai atau dikelola entitas lainnya;

b) Peralatan dan mesin pada tahun 2018 sebesar Rp. 469.400.299.487,92. Jika dibandingkan dengan Aset Tetap Peralatan dan Mesin per 31 Desember 2017 sebesar Rp402.922.063.515,34 maka terdapat peningkatan sebesar Rp66.478.235.972,58 atau meningkat sebesar 16.50\%. Rincian jenis peralatan dan mesin yakni: alat-alat besar, alat-alat angkutan, alat-alat bengkel dan alat ukur, alat-alat peternakan, alat-alat kantor dan rumah tangga, alat-alat studio dan komunikasi, alat-alat kedokteran, alat-alat laboraturium, alat-alat persenjataan, computer, alat produksi, pengolahan dan pemumian, alat keselamatan kerja, alat peraga, peralatan proses/produksi,rambu-rambu, dan peralatan olahraga;

c) Gedung dan bangunan pada tahun 2018 sebesar Rp. 513.393.749.075,93. Jika dibandingkan dengan nilai aset tetap Gedung dan Bangunan per 31 Desember 2017 sebesar Rp. 420.278.544.016,02 maka terdapat peningkatan Gedung dan Bangunan Tahun 2018 sebesar Rp93.115.205.059,91 atau meningkat sebesar 22,15 \%. Rincian jenis Gedung dan bangunan yakni: bangunan Gedung, monument, bangunan Menara, Tugu Titik Kontrol/ Pasti;

d) Jalan, Irigasi dan Jaringan pada tahun 2018 sebesar Rp.788.459.062.832,37. Jika dibandingkan dengan nilai aset tetap Jalan, Irigasi dan Jaringan per 31 Desember 2017 sebesar sebesar Rp826.370.727.311,11 maka terdapat penurunan sebesar Rp37.911.664.478,74 atau menurun sebesar $4,80 \%$. Rincian aset tetap jalan, irigasi dan jaringan, yakni: jalan dan jembatan, bangunan air, instalasi jaringan;

e) Aset Tetap Lainnya pada tahun 2018 sebesar Rp. 30.758.469.978,89. Jika dibandingkan dengan Aset Tetap Lainnya per 31 Desember 2017 sebesar Rp35.148.648.717,47 maka terdapat penurunan sebesar Rp4.390.178.738,58 atau menurun sebesar 12,49\%;

f) Konstruksi dalam Pengerjaan pada tahun 2018 sebesar Rp. 51.399.645.251,06. Jika dibandingkan dengan jumlah Aset Konstruksi dalam Pengerjaan per 31 Desember 2017 sebesar Rp51.145.016.151,92 maka terdapat peningkatan sebesar Rp 254.629.099,14 atau meningkat sebesar $0,49 \%$;

g) Akumulasi Penyusutan pada tahun 2018 sebesar Rp. 771.286.535.093,16. Jika dibandingkan dengan jumlah Akumulasi Penyusutan per 31 Desember 2017 sebesar Rp732.731.640.077,64 maka terdapat 
peningkatan Akumulasi Penyusutan Tahun 2018 sebesar Rp38.554.895.015,52 atau meningkat 5,26 \%. Rincian akumulasi penyusutan per 31 Desember 2018 yakni untuk aset tetap peralatan mesin, Gedung dan bangunan, jalan, irigasi dan jaringan, aset tetap lainnya.

\section{B. Mekanisme Perencanaan Kebutuhan dan Penganggaran Aset Tetap}

Prosedur perencanaan kebutuhan berawal dari dokumen Rencana Pembangunan Jangka Menengah Daerah (RPJMD) untuk jangka waktu 5 tahun. Namun penjabarannya dipilah menjadi pertahun yang di sebut dengan Rencana Strategis (Renstra) lalu akan dilakukan Musyawarah Perencanaan Pembangunan (Musrenbang) dimana dinas dinas akan mengusulkan kegiatan dan kebutuhan selama 1 tahun kedepan. Lalu akan disinkronisasikan dan dievaluasi menjadi revisi perencanaan kebutuhan yang kemudian akan di masukkan dalam RKA-SKPD. Hasil dari dokumen RKA-SKPD akan menjadi dasar untuk penyusunan Kebijakan Umum Anggaran dan Plafon Prioritas Anggaran Sementara (KUA PPAS). Rancangan KUA PPAS diserahkan kepada DPRD untuk dibahas oleh Pemerintah Kota Salatiga dengan Dewan Perwakilan Rakyat Daerah (DPRD) yang kemudian akan dituangkan dalam Nota Kesepakatan.

Rencana strategis yang akan di sahkan harus didasarkan dari kebutuhan dan permasalahan yang sedang terjadi dalam pengelolaan aset tetap.Anggaran yang disetujui dalam Peraturan Daerah APBD dituangkan dalam DPA SKPD. Dalam proses pelaksanaannya berpedoman pada ketentuan yang berlaku dibidang pengelolaan keuangan daerah. Jika dilihat bandingkan dengan mekanisme menurut Morasa et al., (2016), maka sebagian mekanisme perencanaan kebutuhan aset tetap telah memenuhi ketentuan yang ada. Walaupun masih terdapat perbedaan dalam mekanisme penganggaran. Hasil wawancara dengan Pimpinan bidang Anggaran dan Belanja menyatakan, bidang anggaran hanya perlu mengecek, menyesuaikan dan menyetujui anggaran yang akan dikeluarkan. Penyetujuan anggaran juga tidak berbelit asalkan telah memenuhi dokumen yang diperlukan dan telah sesuai dengan DPA.

Berdasarkan hasil wawancara, masalah yang seringkali terjadi di Pemerintah Kota Salatiga ternyata sama dengan fenomena penelitian ini. Fenomena ini pun berkaitan langsung dengan perencanaan kebutuhan aset tetap Masalah yang seringkali terjadi ialah terdapat perbedaan antara kode barang Milik Daerah sesuai peraturan Menteri Dalam Negeri dengan akun Akuntansi (BAS). Pimpinan SKPD bagian aset menyatakan mereka telah memiliki penanganan detektif, yaitu dengan cara melakukan mapping dari kode akun Barang Milik Daerah ke kode akun Akuntansi. Oleh karena itu, walaupun belum dapat dihilangkaan sepenuhnya, namun peneliti menganggap masalah ini tidak memberikan dampak yang besar dalam proses mekanisme perencanaan kebutuhan dan penganggaran.

\section{Akuntabilitas Perencanaan Kebutuhan dan Penganggaran Aset Tetap}

Akuntabilitas perencanaan kebutuhan yang akuntabel ialah pertanggungjawaban kepada pihak yang berhak/ berwenang dan harus didasarkan oleh peraturan perundang-undangan maupun mekanisme perencanaan kebutuhan (Kamaluddin, 2019). Selain itu pertanggungjawaban kepada pihak yang berwenang dilakukan dengan membuat dan menyampaikan output mekanisme perencanaan kebutuhan, yakni: laporan keuangan/dokumen pelaksanaan yang kemudian akan menjadi akuntabilitas Pemerintah atas apa yang sudah di laksanakan selama 1 tahun kedepan.

Terdapat beberapa dokumen terkait dengan perencanaan kebutuhan pertahun, yaitu: (a) RPJMD,(b) Renstra, (c) Rencana Kebutuhan Pengadaan Barang Milik Daerah, (d) Rencana Kebutuhan Pemeliharaan Barang Milik Daerah, (e) RKA-SKPD, (f) KUAPPAS, (g) APBD dan (h) DPA. Selain itu berdasarkan hasil wawancara, undang-undang yang dijadikan pedoman untuk perencanaan kebutuhan, yaitu: (a) Undang-undang 25 tahun 2004 tentang Sistem Perencanaan Pembangunan Nasional, (b) Permendagri 86 tahun 2017 tentang Tata Cara Perencanaan Pembangunan Daerah, Tata Cara Evaluasi Rancangan Peraturan Daerah tentang Rencana Pembangunan Jangka Menengah Daerah, serta Tata Cara Perubahan Rencana Pembangunan Jangka Panjang Daerah, Rencana Pembangunan Jangka Menengah Daerah, dan Rencana Kerja Pemerintah Daerah, (c) Peraturan Pemerintah 58 tahun 2005 tentang Pengelolaan Keuangan Daerah (d) Permendagri 13 tahun 2006 tentang Pedoman Pengelolaan Keuangan Daerah, (e) Permendagri 19 tahun 2016 tentang Pedoman Pengelolaan Barang Milik Daerah (BMN), (f) Permendagri 27 tahun 2014 tentang Pengelolaan Barang Milik Daerah, (g) Peraturan Daerah 15 tahun 2018 tentang Pengelolaan Barang Milik Daerah.

Berdasarkan teori yang ada akuntabilitas penganggaran yang akuntabel dapat diperhatikan dari dokumen/ laporan yang dihasilkan oleh Pemerintah Kota Salatiga. Dokumen yang diperlukan untuk proses pencairan anggaran ialah: (a) Surat Permintaan Pembayaran (SPP), (b) Surat Perintah Membayar (SPM) dan (c) Surat Perintah Pencairan Dana (SP2D). Selain itu untuk dokumen yang dihasilkan dari pelaksana anggaran antara lain: (a) Laporan Realisasi Anggaran (LRA), (b) Laporan Perubahan Saldo Anggaran Lebih, (c) Neraca, Laporan Operasional, (d) Laporan Perubahan Ekuitas, (e) Laporan Arus Kas, 
dan (f) Catatan Atas Laporan Keuangan. Pada dasarnya penganggaran yang akuntabel tidak mesti menggunakan peraturan perundang undangan yang sama setiap tahunnya. Namun dari hasil wawancara bidang Anggaran dan Belanja maupun laporan keuangan Pemerintah Daerah Kota Salatiga terdapat banyak undang-undang yang menjadi dasar dalam proses penganggaran. Beberapa diantaranya, yaitu: Permendagri 55 tahun 2008 tentang Tata Cara Penatausahaan dan Penyusunan Laporan Pertanggungjawaban Bendahara serta Penyampaiannya; Undang-Undang 17 tahun 2003 Tentang Keuangan Negara; Undang-Undang 15 tahun 2004 tentang Pemeriksaan Pengelolaan dan Tanggung Jawab Keuangan Negara; Peraturan Pemerintah 71 tahun 2010 tentang Standar Akuntansi Pemerintah (SAP); Peraturan Daerah kota salatiga 8 tahun 2017 tentang Anggaran Pendapatan dan Belanja Daerah tahun anggaran 2018; Peraturan Daerah Kota Salatiga 23 tahun 2018 tentang Perubahan Anggaran Pendapatan dan Belanja Daerah tahun anggaran 2018; Peraturan Walikota Salatiga 37 tahun 2013 tentang Kebijakan Akuntansi Pemerintah Kota Salatiga, sebagaimana telah diubah beberapa kali terakhir dengan Peraturan Walikota Salatiga 25 tahun 2017.

\section{Simpulan dan saran}

Berdasarkan hasil wawancara masalah ketidakselarasan dokumen terjadi karena Pemerintah Kota Salatiga harus menyesuaikan perubahan amandemen/ peraturan perundang-undangan di bidang pengelolaan Barang Milik Daerah (BMD). Hal ini sering terjadi, mengingat perubahan ini dilakukan oleh Pemerintah Pusat, sehingga dalam perjalanannya Pemerintah Kota Salatiga harus ikut menerapkannya. Namun permasalahan ini sudah memiliki penyelesaian dengan cara melakukan melakukan mapping dari kode akun Barang Milik Daerah ke kode akun Akuntansi. Selain itu, menurut hasil analisis yang telah dilakukan maka dapat ditarik kesimpulan bahwa mekanisme perencanaan kebutuhan dan penggaran Pemerintah Kota Salatiga telah dijalankan secara akuntabel. Hal ini dapat dilihat dari pemenuhan dokumen berdasarkan Permendagri 19 tahun 2016 baik untuk perencanaan kebutuhan maupun penganggaran. Selain itu akuntabilitas berdasarkan perundang-undangan yang dilihat dari ketentuan yang berlaku. Hal ini diakibatkan karena tiap daerah otonomi mempunyai kebijakan masing-masing dan perubahan amandemen. Berdasarkan hasil penelusuran dokumen undang-undang yang digunakan Pemerintah Kota Salatiga mengacu pada Pengelolaan Aset Tetap, SAP, Kebijakan Pemerintah dan Peraturan Walikota.

Penelitian ini masih memiliki keterbatasan dan kekurangan mengingat analisis yang digunakan ialah analisis deskriptif dari hasil wawancara dan berbagai dokumen terkait dengan perencanaan kebutuhan dan penganggaran. Oleh karena itu diharapkan kepada peneliti selanjutnya yang melakukan penelitian serupa agar dapat menggunakan metode analisis dan metode pengumpulan data yang berbeda.

\section{Daftar Rujukan}

Albugis, F. F. (2016). Penerapan Sistem Akuntasni Keuangan Daerah dalam Mewujudkan Transparansi Akuntabilitas Keuangan Pemerintah Daerah Provinsi Sulawesi Utara. Jurnal EMBA, 784(3), 78-89.

Hartanto, N. (2018). Implementasi PP. No. 27 Tahun 2014 Tentang Pengelolaan Barang Milik Negara/ Daerah dalam Upaya Meningkatkan Efektifitas Pengelolaan Barang dan Jasa. Journal of Managemen, 2(3).

Hasan, W. A. (2019). Sistem Pengelolaan Aset Tetap Pada Sekretariat Daerah Kabupaten Buton. Jurnal Ilmiah Akuntansi Manajemen, 2(1), 27-38. https://doi.org/10.35326/jiam.v2i1.252

Hartoko, M. Setiadi. Aset Tetap (Studi Kasus Di Pt Ifca Property365 Indonesia) . Jurnal Akuntansi, Ekonomi dan Manajemen Bisnis Vol. 5 No. 1, July 2017

Honga, A. F., \& Ilat, V. (2014). Analisis Realisasi Anggaran Pendapatan dan Belanja Daerah Pemerintah Kota Bitung. Jurnal EMBA, 2(4), 278-288. https://doi.org/10.1017/CB09781107415324.004

Kamaluddin, S. (2019). Tata Kelola Pemerintahan yang Baik (Good Governance) pada Kantor Distrik Okhika Kabupaten Pegunungan Bintang. Jurnal Ilmu Administrasi Dan Ilmu Pemerintahan, 3(1), 222-228.

Kusen, G. J. (2015). Prinsip Prinsip Hukum Pengelolaan Aset Daerah. Lex et Societatis, III(2), 61-78. 
Labasido, E. R., \& Darwanis, D. (2019). Analisis Pengelolaan Aset Tetap Daerah Pada Dinas Pengelolaan Keuangan Aset Daerah (Dpkad) Provinsi Aceh. Jurnal Ilmiah Mahasiswa Ekonomi Akuntansi, 4(2), 215-236. https://doi.org/10.24815/jimeka.v4i2.12233

Monica, S. G., Saerang, D. P. ., \& Pangerapan, S. (2017). Penerapan Sistem Informas Manajemen Daerah (SIMDA) Barang Milik Daerah pada Badan Pengelola Keuangan dan Aset Daerah Kota Manado. Jurnal Riset Akuntansi Going Concern, 12(2), 304-316.

Morasa, J., Lumenta, A. L., \& Mawikere, L. (2016). Pengaruh Sistem Akuntansi Pemerintah Daerah Dan Ketaatan Peraturan Perundangan Terhadap Akuntabilitas Kinerja Instansi Pemerintah (Kabupaten Minahasa Selatan). Jurnal EMBA, 4(3), 135-146.

Nihayati, A., Dwi, A., \& Bawono, B. (2019). Analisis Penerapan Permendagri Nomor 1 Tahun 2016 tentang Pengelolaan Aset Desa pada Desa Medayu. University Research Colloqium (Urecol), 9(3), 265-274.

Pinatik, S., Ilat, V. I., \& Kolinug, M. S. (2015). Analisis Pengelolaan Aset Tetap Pada Dinas Pendapatan Pengelolaan Keuangan Dan Aset Daerah Kota Tomohon. Jurnal Riset Ekonomi, Manajemen, Bisnis Dan Akuntansi, 3(1), 818-830.

Purba, R. B., \& Aziza, N. (2019). Pengelolaan Aset Tetap Daerah dalam Mengoptimalkan Pemanfaatan Aset Daerah. 9(2), 152-164.

Rizal, Fitri, S. A., \& Rantika, D. (2018). Akuntabilitas dan Transparansi Pengelolaan Anggaran Pendapatan dan Belanja Desa (APBDes) Tahun 2016. Jurnal Al-IQTISHAD, 14(1), 20-37. Retrieved from http://ejournal.uin-suska.ac.id/index.php/al-iqtishad/article/view/5457

Tangkuman, S., \& Mulalinda, V. (2014). Efektivitas Penerapan Sistem Dan Prosedur Akuntansi Aset Tetap Pada Dinas Pendapatan, Pengelolaan Keuangan Dan Aset Daerah Kabupaten Sitaro. Jurnal Riset Ekonomi, Manajemen, Bisnis Dan Akuntansi, 2(1), 521-531.

Wonggow, A., Ilat, V., \& Affandi, D. (2014). Kajian Mengenai Pengelolaan Barang Milik Daerah Di Pemerintah Kota Manado Menurut Permendagri No. 17 Tahun 2007. Jurnal Riset Ekonomi, Manajemen, Bisnis Dan Akuntansi, 2(1), 582-593.

Zawawi, M. (2016). Chabib Soleh \& Heru Rochmansjah, Pengelolaan Keuangan dan Aset daerah, Fokus Media, Bandung, 2010. Model Akuntabilitas Kinerja Skpd Dalam Mewujudkan Good Governance. Jurnal Pemerintahan Dan Politik, 1(1), 8-13. Retrieved from http://ejournal.uigm.ac.id/index.php/PDP/article/view/693/844 